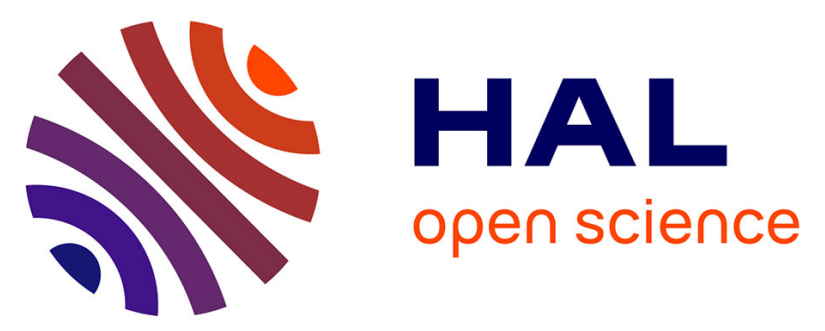

\title{
Combined geochemical and electrochemical methodology to quantify corrosion of carbon steel by bacterial activity.
}

Marta K Schütz, Rebeca Leite de Souza Moreira, Olivier Bildstein, Jean-Eric Lartigue, Michel L Schlegel, Bernard Tribollet, Vincent Vivier, Marie Libert

\section{To cite this version:}

Marta K Schütz, Rebeca Leite de Souza Moreira, Olivier Bildstein, Jean-Eric Lartigue, Michel L Schlegel, et al.. Combined geochemical and electrochemical methodology to quantify corrosion of carbon steel by bacterial activity.. Bioelectrochemistry, 2014, 97, pp.61-68. 10.1016/j.bioelechem.2013.07.003 . hal-01009685

\section{HAL Id: hal-01009685 \\ https://hal.sorbonne-universite.fr/hal-01009685}

Submitted on 17 Oct 2014

HAL is a multi-disciplinary open access archive for the deposit and dissemination of scientific research documents, whether they are published or not. The documents may come from teaching and research institutions in France or abroad, or from public or private research centers.
L'archive ouverte pluridisciplinaire HAL, est destinée au dépôt et à la diffusion de documents scientifiques de niveau recherche, publiés ou non, émanant des établissements d'enseignement et de recherche français ou étrangers, des laboratoires publics ou privés. 


\title{
Combined geochemical and electrochemical methodology to quantify corrosion of carbon steel by bacterial activity
}

\author{
Marta K. Schütz ${ }^{a, d, *}$, Rebeca Moreirac, Olivier Bildsteina ${ }^{a}$, Jean-Eric Lartigue ${ }^{a}$, Michel L. \\ Schlegel ${ }^{b}$, Bernard Tribollet ${ }^{c}$, Vincent Vivier ${ }^{c}$, Marie Libert ${ }^{a}$ \\ ${ }^{a}$ CEA, DEN, DTN/SMTM/LMTE, 13108 Saint Paul lez Durance, France \\ ${ }^{b}$ CEA, DEN, DANS/DPC/SCP/LRSI, F91191 Gif-sur-Yvette, France \\ cUPR 15 du CNRS, Laboratoire Interfaces et Systèmes Electrochimiques, Université Pierre et \\ Marie Curie, T22, 4 Place Jussieu, 75252 Paris Cedex 05, France \\ dAix-Marseille Université, Sciences de l'Environnement, 13545 Aix en Provence, France
}

AUTHOR EMAIL ADDRESS: martakerber@gmail.com (M. Schütz)

CORRESPONDING AUTHOR FOOTNOTE Tel.: +33 4 42254942; fax: +33442256272

\begin{abstract}
The availability of respiratory substrates such as $\mathrm{H}_{2}$ and $\mathrm{Fe}(\mathrm{II}, \mathrm{III})$ solid corrosion products within nuclear waste repository, will sustain the activities of hydrogen-oxidizing bacteria (HOB) and iron-reducing bacteria (IRB). This may have a direct effect on the rate of carbon steel corrosion. This study investigates the effects of Shewanella oneidensis (an HOB and IRB model organism) on the corrosion rate by looking at carbon steel dissolution in the presence of $\mathrm{H}_{2}$ as the sole electron donor. Bacterial effect is evaluated by means of geochemical and electrochemical techniques. Both showed that the corrosion rate is enhanced by a factor of 2-3 in the presence of bacteria. The geochemical experiments indicated that the composition and crystallinity of the solid corrosion products (magnetite and vivianite) are modified by bacteria. Moreover, the electrochemical experiments evidenced that the bacterial activity can be stimulated when $\mathrm{H}_{2}$ is generated in a small confinement volume. In this case, a higher corrosion rate and mineralization (vivianite) on the carbon steel surface were observed. The results suggest that the mechanism likely to influence the corrosion rate is the bioreduction of $\mathrm{Fe}(\mathrm{III})$ from magnetite coupled to the $\mathrm{H}_{2}$ oxidation.
\end{abstract}

Keywords: biocorrosion, iron-reducing bacteria, dihydrogen, SEM micrographs, Raman microspectroscopy, chronoamperometry 


\section{Introduction}

Disposal of high-level nuclear waste (HLW) in deep geological repositories is increasingly considered as a reliable solution in many countries. In France, for example, the current option explored is to store the vitrified HLW in stainless steel containers, conditioned in carbon steel overpacks which are then emplaced in a deep underground repository (about 500 $\mathrm{m}$ deep) in an argillaceous formation (claystone). This is known as a multi-barrier system, designed to ensure long-term radionuclide confinement. One of the purposes of the multibarrier system is to prevent water circulation around the metallic packages, thus preventing corrosion in water-saturated conditions.

However, knowledge about steel corrosion processes, especially over a long time period, must still be expanded to ensure that geological disposals will remain safe over a period of several hundreds of thousand years. The main issues related to steel corrosion are the influences of physico-chemical conditions (e.g. water saturation, pressure, temperature, $\mathrm{pH}$, redox potential), and consequently microbial activity, on the durability of the different metallic packages.

Several studies reveal the presence of microorganisms in most of the deep clay formations already investigated, such as Callovo-Oxfordian argillite and Opalinus clay [1,2]. Therefore, an impact of the microbial activity can be expected with respect to the various phenomena that may occur within the repository, such as (i) radionuclide migration through clay formations (including effects of biofilms); (ii) build-up of the gas phase by microbial gas production; and (iii) Microbiologically Influenced Corrosion (MIC) or biocorrosion [3,4] which is discussed in this study.

Energetic compounds and nutrients are available to support microbial activity under geological conditions. Nutrients may be present either as soluble species in the groundwater or in minerals (solid-associated forms). Among the energetic compounds, $\mathrm{H}_{2}$ is expected to be one of the most efficient substrates (acting as an electron donor) [5]. It can be produced by radiolytic dissociation of water or by anoxic aqueous metallic corrosion [6,7]. Moreover, $\mathrm{Fe}(\mathrm{III})$ from clay minerals [8,9] and corrosion products, such as magnetite $\left(\mathrm{Fe}_{3} \mathrm{O}_{4}\right)$ [10-14], could be a significant electron acceptor for anaerobic microbial respiration (by dissimilatory processes). The availability of such substrates may sustain the development of hydrogen-oxidizing bacteria $(\mathrm{HOB})$ and iron-reducing bacteria (IRB), which in turn could have an impact on geochemical and corrosion processes in deep geological environments.

Several studies have dealt with the impact of sulfate-reducing bacteria (SRB) [15-18] on corrosion processes. In contrast, the impact of IRB species has been only marginally investigated. Their role in biocorrosion is still under debate; either an inducing or an inhibitory effect by formation of a protective biofilm on metal surface have been hypothesized [19-21]. Recent studies have investigated the impact of IRB on metallic corrosion processes under geological disposal conditions [22-24]. IRB species can use Fe(III) from magnetite or other $\mathrm{Fe}(\mathrm{III})$ (hydr)oxides as electron acceptor in the presence of $\mathrm{H}_{2}$ as electron donor. An alteration of the (hydr)oxide layers with a possible reactivation of the corrosion process may thus occur as a consequence of the Fe(III) bacterial respiration [22].

This study investigates the effect of the HOB and IRB activities on the corrosion rate of carbon steel in the presence of $\mathrm{H}_{2}$ as the sole electron donor. These investigations are supported by geochemical and electrochemical techniques. Geochemical analysis allows the monitoring of the metal dissolution and the formation of $\mathrm{Fe}(\mathrm{II}, \mathrm{III})$ solid corrosion products during the bacterial oxidation of $\mathrm{H}_{2}$ produced by corrosion. Local electrochemical techniques allow to generate a high $\mathrm{H}_{2}$ concentration for bacterial metabolism and then to probe the bacterial reaction in terms of modification of the local potential. 


\section{Materials and methods}

\subsection{Bacterial culture}

Shewanella oneidensis strain MR-1 (ATCC $700550^{\mathrm{TM}}$ ) was chosen as a model of IRB and $\mathrm{HOB}$. Cultures were obtained aerobically at the beginning of stationary growth phase in Luria Bertani Broth (LB) medium ( $5 \mathrm{~g} \mathrm{~L}^{-1} \mathrm{NaCl}, 10 \mathrm{~g} \mathrm{~L}^{-1}$ tryptone, $5 \mathrm{~g} \mathrm{~L}^{-1}$ yeast extract) after 24 $\mathrm{h}$ at $30^{\circ} \mathrm{C}$ under sterile conditions. Bacterial cells were harvested from the LB medium by centrifugation (4000 rpm for $20 \mathrm{~min}$ ), washed once with sterile minimal medium (M1) and then inoculated in the batch reactors (initial concentration $10^{8}$ cells $\mathrm{mL}^{-1}$ counted by epifluorescence method with LIVE/DEAD ${ }^{\circledR}$ BacLight ${ }^{\mathrm{TM}} \mathrm{kit}$ ). The chemically defined minimal medium (M1) was prepared according to Kostka and Nealson (1998) [25]. However, minor modifications were made to the composition [22] in order to obtain a representative solution of the groundwater found in the argillaceous formations for geological disposal in France. The final composition is shown in Table 1.

\section{Here Table 1}

The $\mathrm{pH}$ was adjusted to ca. 7 with $\mathrm{NaOH}$ and then the medium was sterilized by autoclaving $\left(120^{\circ} \mathrm{C}\right.$ for $\left.20 \mathrm{~min}\right)$, except for the thermolabile components (e.g. amino acids) which were filter-sterilized $(0.22 \mu \mathrm{m})$ and added to the autoclaved medium.

\subsection{Carbon steel coupons}

Corrosion studies were performed with low carbon steel coupons A37 supplied by the French Alternative Energies and Atomic Energy Commission (CEA). They contain $0.12 \% \mathrm{C}$, $0.22 \% \mathrm{Si}, 0.62 \% \mathrm{Mn}, 0.008 \% \mathrm{Al}, 0.012 \% \mathrm{~S}, 0.012 \% \mathrm{P}, 0.02 \% \mathrm{Ni}, 0.03 \% \mathrm{Cr}, 0.04 \% \mathrm{Cu}$, $0.005 \%$ Co and $<0.005 \% \mathrm{Ti}$. Carbon steel is a corrosion-allowance material which is expected to have nearly-uniform corrosion in a reducing environment, and has been therefore considered as a candidate material for packages used in the geological disposal.

The cylindrical coupons were laterally insulated from the solution by a diallylphthalate glass-fiber resin (Presi) in order to expose only an active surface of $0.78 \mathrm{~cm}^{2}$. Then, the coupons were polished with 600 grit SiC abrasive paper and sterilized with ethanol by sonication for 15 min prior to the experiments.

\subsection{Batch experiments}

All experiments started under strictly sterile conditions in batch reactors at $30^{\circ} \mathrm{C}$ under an anaerobic atmosphere. Both abiotic and biotic conditions were investigated.

\subsubsection{Geochemical techniques}

The geochemical experiments were performed in triplicate in $140 \mathrm{~mL}$ of $\mathrm{M} 1$ medium under $\mathrm{N}_{2} / \mathrm{CO}_{2}(90: 10 \%)$ atmosphere. The corrosion reaction was monitored as a function of time by gas and solution analyses. The aqueous Fe concentration was analyzed by Inductively Coupled Plasma Optical Emission Spectrometry (ICP-OES, Varian, VISTA-MPX) after 0.02 $\mu \mathrm{m}$ filtration and $2 \%(\mathrm{v} / \mathrm{v}) \mathrm{HNO}_{3}$ acidification. The analysis of $\mathrm{H}_{2}$ in the headspace was carried out by Micro Gas Chromatography (Varian, CP-4900) using a thermal conductivity detector with $\mathrm{N}_{2}$ as carrier gas. The total $\mathrm{H}_{2}$ concentration was calculated as the sum of the concentrations in the gas and the aqueous phases (determined using Henry's law). 


\subsubsection{Electrochemical techniques}

The electrochemical measurements were performed with a home-made Scanning Electrochemical Microscope (SECM) [26,27] in a 4-electrode cell configuration elaborated specifically for anaerobic and sterile conditions. The double wall glass cell was equipped with the carbon steel working electrode (WE1) placed in the bottom of the cell, and with a platinum probe of $50 \mu \mathrm{m}$ in radius acting as a second mobile working electrode (WE2) for generating $\mathrm{H}_{2}$. The cell was sealed with a Teflon cover and the platinum WE2 probe was placed through a nitrile flexible support on the cover, perpendicular to WE1, in a way to allow its displacement for the measurements. The WE2 microelectrode was positioned with the help of motorized stages driven by a motion controller (Newport) with Labview software. Both working electrodes used as reference a saturated calomel electrode (SCE) and a platinum grid as counter electrode.

The disassembled cell and the platinum WE2 probe were sterilized prior to the experiments with $70 \%$ ethanol solution for $20 \mathrm{~min}$; then rinsed with sterilized water in a laminar flow chamber and finally UV-irradiated for $15 \mathrm{~min}$. The lugging capillary (for holding the reference electrode) and the platinum grid counter electrode were sterilized in autoclave. The cell was assembled under sterile conditions and $230 \mathrm{~mL}$ of $\mathrm{M} 1$ medium was introduced and deaerated for $2 \mathrm{~h}$ under $\mathrm{N}_{2}$ atmosphere. The $\mathrm{N}_{2}$ flow was maintained at the cell headspace (near to the liquid surface) so as to ensure the anaerobic conditions during the whole electrochemical measurements. A supplementary $\mathrm{N}_{2}$ bubbling of the bulk solution was also carried out during inoculation of the electrochemical cell.

An approach curve was performed at a rate of $7.5 \mu \mathrm{m} \mathrm{s}^{-1}$ with the probe polarized at -0.9 V/SCE and the substrate held at Open Circuit Potential (OCP). Such approach curve allowed the contact point between the steel substrate and the apex of the probe to be determined with a spatial resolution better than a fraction of micrometer. Then, the microelectrode was repositioned at $50 \mu \mathrm{m}$ from the substrate and polarized for generating locally $\mathrm{H}_{2}$ (Scheme 1). The use of SECM for generation or collection of $\mathrm{H}_{2}$ in solution has already been described in the literature $[28,29]$.

\section{Here Scheme 1}

\subsection{Characterization of the coupon surface}

Steel coupon surfaces in the geochemical experiments were analyzed, after 5 months of reaction, by Raman microspectroscopy and Scanning Electron Microscopy (SEM). The coupon surfaces of the electrochemical experiments were analyzed only by SEM. The samples for the Raman analysis were kept in anoxic containers and the measurements were performed through a glass plate (500 $\mu \mathrm{m}$ thick) using a LabRam HR (Horiba Jobin Yvon) spectrometer equipped with a $532 \mathrm{~nm}$ laser and a 50x long range lens. The laser power was $50 \mathrm{~mW}$ attenuated by a factor of 100 . The acquisition time ranged from 60 to $600 \mathrm{~s}$ depending on the spectral quality. The Raman spectra are presented in this study without smoothing or line fitting. The spectra analysis was performed by comparing the significant bands with literature data [30-34]. SEM studies were performed at $20 \mathrm{keV}$ and $5.3 \mathrm{nA}$ with a Leica Stereoscan 440 microscope coupled with Energy Dispersive Spectroscopy (EDS) for elemental semi-quantitative analyses (Princeton Gamma-Tech). The samples were slightly rinsed with deionised water, dried with $\mathrm{N}_{2}$ gas and stored in plastic containers until analysis. The coupons were carbon coated prior to SEM analysis. 


\section{Results and discussion}

\subsection{Geochemical results}

Under anaerobic conditions, carbon steel corrosion (simplified as Fe in the Eqs. 1 \& 3) is described by iron oxidation as the anodic reaction (Eq. 1) and water reduction as the cathodic reaction (Eq. 2):

$\mathrm{Fe} \rightarrow \mathrm{Fe}^{2+}+2 \mathrm{e}^{-}$

$2 \mathrm{H}_{2} \mathrm{O}+2 \mathrm{e}^{-} \rightarrow 2 \mathrm{HO}^{-}+\mathrm{H}_{2}$

According to the overall reaction (Eq. 3), the molecular stoichiometry of Fe: $\mathrm{H}_{2}$ produced by corrosion is $1: 1$ :

$\mathrm{Fe}+2 \mathrm{H}_{2} \mathrm{O} \rightarrow \mathrm{Fe}^{2+}+2 \mathrm{OH}^{-}+\mathrm{H}_{2}$

Figure 1 shows the evolution of $\mathrm{Fe}$ and $\mathrm{H}_{2}$ produced by carbon steel corrosion.

\section{Here Fig. 1}

In abiotic conditions, equimolar $\mathrm{H}_{2}$ and dissolved $\mathrm{Fe}$ are released, which is in good agreement with the stoichiometry of the Eq. (3). Effective biocorrosion was evidenced by the larger amounts of $\mathrm{Fe}$ and $\mathrm{H}_{2}$ produced at about 5 days compared to abiotic conditions. Moreover, in presence of bacteria, $\mathrm{H}_{2}$ concentration remains much lower when compared to dissolved Fe concentration. Such evidence suggests that bacteria consume the soluble $\mathrm{H}_{2}$ in the aqueous phase for respiration. Several studies have indeed shown that $\mathrm{H}_{2}$ is an important energetic substrate, especially in disposal environments where only low amounts of biodegradable organic matter are available [5,7,35].

The $\mathrm{pH}$ in the bulk solution was initially equal to 6.47 and only a slight increase was observed at the end of the experiments for both abiotic and biotic conditions, with values of 6.54 and 6.62, respectively (data not shown).

A black layer and a white precipitate (over the black layer) were progressively formed on the coupon surface in both abiotic and biotic conditions, suggesting a reaction between the surface and species in solution which also resulted in a decrease in the aqueous $\mathrm{Fe}$ concentration after 20 days of reaction (results not shown in Figure 1). The Raman analysis for the solid corrosion products formed in abiotic conditions (Figure 2a) revealed the presence of vivianite $\left(\mathrm{Fe}_{3}\left(\mathrm{PO}_{4}\right)_{2} .8 \mathrm{H}_{2} \mathrm{O}\right)$ (i \& iii) and magnetite (ii) as the most abundant mineral phases. In contrast, for the biotic conditions (Figure $2 \mathrm{~b}$ ), the intensity of vivianite bands is greater (i \& iii); the intensity of magnetite band significantly decreases (ii); and relatively intense bands appear in the region $1440 \mathrm{~cm}^{-1}$ (iv), which may indicate cellular compounds (e.g. lipids, enzymes like hydrogenase) on the coupon surface. The magnetite band is broad, suggesting formation of a mineral phase with poor crystallinity.

\section{Here Fig. 2}

The SEM analysis also revealed vivianite as corrosion product for both abiotic (Figures $3 a \& b)$ and biotic (Figures $3 e$ \& f) conditions. A modification in the morphology of this mineral was observed in the presence of bacteria. Moreover, in biotic conditions the black layer morphology and chemical composition are modified (Figures $3 g \& \mathrm{~h}$ ), compared to those in abiotic conditions (Figures $3 c \& d$ ). Both Raman and SEM analyses point out a modification of the composition and crystallinity of corrosion products by the bacterial activity. 
The literature proposes different mechanisms of bacterial-induced corrosion. Widdel's group have hypothesized that, in the case of SRB and methanogenic species, corrosion is enhanced by direct electron transfer from metal to bacterial cells $[18,36]$. In contrast, we can assume that, in the case of IRB species, dissimilatory reduction of $\mathrm{Fe}(\mathrm{III})$ promotes the solubilization and removal of (hydr)oxide layers, exposing carbon steel surfaces to corrosion $[21,22]$. To date, direct contact, nanowires and electron shuttling have been proposed as strategies for dissimilatory $\mathrm{Fe}(\mathrm{III})$ reduction from insoluble substrates [37]. Our results corroborate these findings, showing that Shewanella oneidensis can reduce $\mathrm{Fe}$ (III) from magnetite using soluble $\mathrm{H}_{2}$ produced during the corrosion process as an electron donor.

\section{Here Fig. 3}

\subsection{Electrochemical results}

Figure 4 shows the OCP variation of the carbon steel electrode in the M1 solution. Such measurement indicates the variation of the difference of potential between the carbon steel working electrode and the reference electrodes at the equilibrium state over time. The OCP remains stable at $-714 \mathrm{mV} / \mathrm{SCE}$ during the first $16 \mathrm{~h}$ of the experiment. Then, the supplementary $\mathrm{N}_{2}$ bubbling of the solution for $1 \mathrm{~h}$ is accompanied by a small decrease of the potential (about $23 \mathrm{mV}$ ). The OCP is slightly perturbed upon addition of the Shewanella oneidensis inoculum, but then it slightly decreases and stabilizes at ca. $-718 \mathrm{mV} / \mathrm{SCE}$ after a few hours.

\section{Here Fig. 4}

After mapping experiments (data not shown), in which the platinum probe was polarized to generate $\mathrm{H}_{2}$, we noticed a formation of solid phases over the entire surface of the steel substrate (Figure 5a). SEM micrograph of the substrate at the position where the $\mathrm{H}_{2}$ was locally generated (target area in Figure 5a) is shown in Figure 5b. A more important mineralization was observed on this specific area, in the vicinity of the probe, where $\mathrm{H}_{2}$ was kept in a confinement volume (ca. $\left.3.9 \times 10^{-8} \mathrm{~cm}^{3}\right)$. This observation suggests an influence of the corrosion increase in this localized area. Changes in the local $\mathrm{pH}$, redox potential, or even the enhancement of the bacterial activity due to a greater availability of energetic substrate $\left(\mathrm{H}_{2}\right)$ can be considered as potential factors for the mineralization effect. The EDS analysis of a single crystal (Figures $5 d \&$ c, respectively) shows the formation of iron phosphate as vivianite.

\section{Here Fig. 5}

During the corrosion process two phenomena take place simultaneously - the anodic reaction (Eq. 1) and the cathodic reaction (Eq. 2). At the equilibrium (OCP), the net current in the substrate is zero. When the potential of the steel electrode is set to a value greater than the OCP, the anodic dissolution of the substrate is favored. We thus biased the substrate state in order to control the kinetics of dissolution and we locally generated $\mathrm{H}_{2}$ through the probe brought to the vicinity of the substrate. The distance between the steel substrate and the probe was set at $50 \mu \mathrm{m}$ by performing a preliminary approach curve [38]. With such a device (sketched in Scheme 1), it was possible to reproduce and to control the different processes that usually take place simultaneously on the steel electrode.

The steel dissolution was monitored over 5 days for different corrosion conditions by measuring the total current of the electrode in order to reveal the influence of the local $\mathrm{H}_{2}$ concentration (Figure 6). The corrosion rate was shown to depend on the presence of both bacteria and the $\mathrm{H}_{2}$ generated. When the potential of the steel electrode is biased at OCP, in the abiotic conditions and without $\mathrm{H}_{2}$ generation (Figure 6, curve a), the current remains in 6 
the range of $0.5 \mu \mathrm{A} \mathrm{cm}{ }^{-2}$. In contrast, when $\mathrm{H}_{2}$ is generated, the current of the steel electrode increases to about $1 \mu \mathrm{A} \mathrm{cm}^{-2}$ and remains in a quasi steady-state regime (Figure 6, curve b). The positive feedback regime that takes place between the probe and the substrate explains this behavior [38]. In biotic conditions, a steady increase of the current is observed during the 5 days (Figure 6 , curve c).

\section{Here Fig. 6}

The integration of the anodic current of each experiment provides the exchanged charge during the corrosion process (Table 2). These results clearly indicate that in biotic conditions and with local $\mathrm{H}_{2}$ generation, the corrosion magnitude is significantly increased due to an increase of the bacterial activity (the more dihydrogen is produced, the more the consumption of iron by the bacteria). It is noteworthy that these experiments do not allow the measurements of the $\mathrm{H}_{2}$ produced by the corrosion process, only the $\mathrm{H}_{2}$ generated by the probe.

\section{Here Table 2}

Again, the carbon steel surface exhibited a mineralization as iron phosphate. It should also be mentioned that longer experiments (more than 5 days) are usually difficult to perform in such experimental conditions, since the distance between the probe and the substrate is small $(50 \mu \mathrm{m})$ so as to confine the $\mathrm{H}_{2}$ generation. Hence, the biocorrosion can lead to accumulation of corrosion or biological products between the probe and the substrate. Bacterial adhesion on the carbon steel surface can also be observed after the experiments, as shown in Figure 7, which is an another indication of the bacterial action on the corrosion process.

\section{Here Fig. 7}

\subsection{Corrosion rate results}

The corrosion rates were obtained from the results of the geochemical and electrochemical experiments. In the case of geochemical measurements, the corrosion rate was estimated from the aqueous Fe concentration (shown in Figure 1), according to Eq. (3) and assuming no precipitation of corrosion products during the first 20 days of reaction. In contrast, in the case of electrochemical measurements, the charges for steel corrosion obtained for 5 days were converted considering the general value for steel $(j=86.3 \mu \mathrm{A} \mathrm{cm}-2$ equal a corrosion rate of $1 \mathrm{~mm}^{\text {year }}{ }^{-1}$ ) [39].

Figure 8 and Table 2 show the corrosion rates obtained from the geochemical and electrochemical results, respectively. Figure 8 shows that the short-term corrosion rate is higher than the long-term one for both abiotic and biotic conditions. The bacterial effect on the corrosion rate tends to decrease with time, suggesting a depletion of nutrients because of experimental conditions (batch reactors) leading to a limitation of bacterial development. Average rates are estimated at $100 \mu \mathrm{m}$ year $^{-1}$ and $30 \mu \mathrm{m}$ year-1 for biotic and abiotic conditions, respectively, after a period of about 20 days.

\section{Here Fig. 8}

The corrosion rates obtained by the electrochemical results (Table 2) show values that are significantly smaller when compared to the geochemical results because of the choice of the potential applied for the measurements. At OCP, anodic and cathodic currents are contributing to the overall reaction and, in this case, the cathodic reaction (water reduction) is 7 
not taken into account and the anodic current (steel dissolution) value is therefore underestimated. Although the corrosion rate values obtained in the electrochemical and geochemical experiments cannot be directly compared, they demonstrate a clear influence of the bacterial activity. The corrosion rates are shown to be greater in biotic than abiotic conditions with both techniques.

\section{Conclusions}

Safe disposal of HLW is a key issue of waste management. The current disposal concept relies on a multi-barrier system which includes different metallic packages (stainless steel, carbon steel). Over time, production of $\mathrm{H}_{2}$ and $\mathrm{Fe}(\mathrm{II}, \mathrm{III})$ solid corrosion products is expected due to the anoxic aqueous corrosion. Such corrosion products can provide respiratory substrates for bacterial activities. Therefore, the influence of the biological parameter on corrosion has to be also evaluated in order to demonstrate the safety of the disposal system.

This study demonstrates that the corrosion process is enhanced by a factor of 2-3 in presence of bacteria. The geochemical results showed that after 5 days a greater amount of $\mathrm{Fe}$ and $\mathrm{H}_{2}$ is produced during corrosion in comparison with abiotic conditions. Moreover, the consumption of the soluble $\mathrm{H}_{2}$ in the aqueous phase by bacteria is evidenced as well as a modification in the composition and crystallinity of the solid corrosion products (magnetite and vivianite) on the carbon steel surface. Still, the electrochemical results showed a higher mineralization (vivianite) and corrosion rate in presence of bacteria when $\mathrm{H}_{2}$ is generated in a small confinement volume (ca. $3.9 \times 10^{-8} \mathrm{~cm}^{3}$ ). So, our results suggest that Shewanella oneidensis likely induces corrosion by reduction of $\mathrm{Fe}(\mathrm{III})$ from magnetite using soluble $\mathrm{H}_{2}$ produced by the corrosion process as electron donor.

However, it remains to be determined if the bacterial activity will have a similar longterm effect on the corrosion rate under disposal conditions. A modeling approach, including calibrated parameters according to the results of the short-term experiments, could be used to extrapolate the corrosion kinetics and predict biocorrosion processes on a long-term scale. 


\section{Author CVs}

Marta Kerber Schütz received a BS degree in Industrial Chemistry from Catholic University of Rio Grande do Sul, Porto Alegre, Brazil in 2007; completed her MSc in Materials Science and Engineering in March 2010 at the same University. Now she is a PhD student at the French Commission for Atomic Energy and Alternative Energies (CEA). She is working on biocorrosion phenomena implicated on the radioactive waste geological disposal. The overall objective of her study is to better understand the impact of bacterial activities (notably IRB species) on the corrosion products (dihydrogen and iron (hydr)oxides) and on the rate of anoxic corrosion.

Rebeca Moreira is graduated in Food Engineering with a Master degree in Quality Control in Food and Drink Industries in Rio de Janeiro, Brazil. Started the PhD study in 2010 as a member of the BIOCOR Program at the Laboratory of Interfaces and Systems Electrochemistry (University Pierre et Marie Curie), Paris, France. The subject of her work is the study of the biocorrosion of carbon steel using local electrochemical techniques.

Olivier Bildstein received his PhD in geochemistry (1998) from the University of Strasbourg. $\mathrm{He}$ is a senior research engineer at the French Commission for Atomic Energy and Alternative Energies (CEA) since 2000, after a postdoctoral stay at LLNL (California, USA). His previous affiliations include a doctoral fellowship at the French Institute for Petroleum (1994-1998) and a position as hydrogeologist at the French Geological Survey (BRGM) (1993). His research focuses on numerical modeling of reactive, multicomponent, and multiphase flow and transport with application to long term evolution of materials in radioactive waste disposal, subsurface pollution/remediation, and potential bacteria mediated processes.

Jean-Eric Lartigue received his $\mathrm{PhD}$ in experimental geochemistry (1994) from the University of Marseilles (France). He is a research engineer at the French Commission for Atomic Energy and Alternative Energies (CEA) since 1998 after a postdoctoral fellowship at CEA (19951998). His research focuses on water rock-interactions with: a) experimental measurements of minerals and conditioning matrices for long live radionuclide dissolution kinetic rates law and b) reactive-transport modelling of materials long term behaviour in a radioactive waste disposal context.

Michel Schlegel was received at the Ecole Normale Supérieure of Lyon in 1992. He received his PhD degree at the University of Grenoble in 2000 and worked as a postdoctoral fellow at the University of Colorado at Boulder from 2000 to 2001. He is now a research engineer and a senior expert at the Commissariat à l'Energie Atomique et aux Energies Alternatives. His research topics include metal corrosion and speciation of trace (radio)elements in complex environmental matrices (complexation, interaction with mineral surfaces).

Bernard Tribollet after his graduation from the "Ecole Supérieure d'Electricité" (1973), joined the laboratory of I. Epelboin (now LISE-CNRS UPR 15) where he prepared a PhD under his supervision. In 1981, with the support of a NSF fellowship, he spent one year as visiting scientist at the University of California, Berkeley under the supervision of Prof. John Newman. His current research field concerns different problems: mass transport, electrodissolution, corrosion and in particular biocorrosion. He co-authored, with Prof. Mark Orazem of the University of Florida, a textbook on impedance spectroscopy published in 2008 as part of the Electrochemical Society Series (Wiley).

Vincent Vivier was born in Saint-Maur (France) in 1971. He received his PhD in 2000 under 
the supervision of Dr. L.T. Yu in Thiais (France). In 2002, he joined the Laboratoire Interfaces et Systèmes Électrochimiques (CNRS - UPR 15). His current research field concerns the characterization of heterogeneous interface reactivity by means of local electrochemical techniques and electrochemical impedance spectroscopy.

Marie Libert received her PhD in biochemistry (1986) from the University of CompiegneFrance. She is a senior research engineer at the French Commission for Atomic Energy and Alternative Energies (CEA) since 1998. Her previous affiliation includes a doctoral fellowship at the same university. Her research focuses on different fields such as the effect of microorganisms on long term behaviour of materials used in nuclear repository, biocorrosion, impact of radioactive emission on biota, anaerobic microbiology. She was and she is an European expert on several international research programs. 


\section{Acknowledgements}

The authors thank Damien Féron (CEA Saclay, France) for carbon steel samples, Paul Soreau (IBEB, CEA Cadarache, France) for ICP-OES analysis and Françoise Pillier (LISE, UPR15, France) for SEM analysis. This research has received funding from the European Community's Seventh Framework Programme (FP7/2007-2013) under grant agreement $n^{\circ}$ 238579 by the BIOCOR ITN project (website: www.biocor.eu/). 


\section{References}

[1] S. Stroes-Gascoyne, C.J. Hamon, D.A. Dixon, J.B. Martino, Microbial analysis of samples from the tunnel sealing experiment at AECL's Underground Research Laboratory, Phys. Chem. Earth, 32 (2007) 219-231.

[2] S. Poulain, C. Sergeant, M. Simonoff, C. Le Marrec, S. Altmann, Microbial investigation of Opalinus Clay, an argillaceous formation under evaluation as a potential host rock for a radioactive waste repository, Geomicrobiol. J. 25 (2008) 240-249.

[3] M.J. Keith-Roach, F.R. Livens, Microbial interactions with radionuclides - summary and future perspectives, in: Interactions of Microorganisms with Radionuclides, Elsevier, 2002, pp. 383-391.

[4] S. Stroes-Gascoyne, J.M. West, An overview of microbial research related to high-level nuclear waste disposal with emphasis on the canadian concept for the disposal of nuclear fuel waste, Can. J. Microbiol. 42 (1996) 349-366.

[5] L.H. Lin, G.F. Slater, B.S. Lollar, G. Lacrampe-Couloume, T.C. Onstott, The yield and isotopic composition of radiolytic $\mathrm{H}_{2}$, a potential energy source for the deep subsurface biosphere, Geochim. Cosmochim. Acta 69 (2005) 893-903.

[6] G. Galès, M.F. Libert, R. Sellier, L. Cournac, V. Chapon, T. Heulin, Molecular hydrogen from water radiolysis as an energy source for bacterial growth in a basin containing irradiating waste, FEMS Microbiol. Lett. 240 (2004) 155-162.

[7] M. Libert, O. Bildstein, L. Esnault, R. Sellier, Molecular hydrogen: An abundant energy source for bacterial activity in nuclear waste repositories, Phys. Chem. Earth. 36 (2011) 16161623.

[8] J.E. Kostka, J.W. Stucki, K.H. Nealson, J. Wu, Reduction of structural Fe(III) in smectite by a pure culture of Shewanella putrefaciens strain MR-1, Clays Clay Min. 44 (1996) 522-529.

[9] J.E. Kostka, J. Wu, K.H. Nealson, J.W. Stucki, The impact of structural Fe(III) reduction by bacteria on the surface chemistry of smectite clay minerals, Geochim. Cosmochim. Acta 63 (1999) 3705-3713.

[10] J.E. Kostka, K.H. Nealson, Dissolution and Reduction of Magnetite by Bacteria, Environ. Sci. Technol. 29 (1995) 2535-2540.

[11] M.K. Schütz, M. Libert, M.L. Schlegel, J.E. Lartigue, O. Bildstein, Dissimilatory Iron Reduction in presence of Hydrogen: A case of Microbial Activity in the Nuclear Waste Disposal, Procedia Earth and Planet. Sci. 7 (2013) 409-412.

[12] O. Bildstein, L. Trotignon, M. Perronnet, M. Jullien, Modelling iron-clay interactions in deep geological disposal conditions, Phys. Chem. Earth. 31 (2006) 618-625.

[13] F.A. Martin, C. Bataillon, M.L. Schlegel, Corrosion of iron and low alloyed steel within a water saturated brick of clay under anaerobic deep geological disposal conditions: An integrated experiment, J. Nucl. Mater. 379 (2008) 80-90. 
[14] M.L. Schlegel, C. Bataillon, K. Benhamida, C. Blanc, D. Menut, J.-L Lacour, Metal corrosion and argillite transformation at the water-satured, high temperature iron-clay interface: A microscopic-scale study, Appl. Geochem. 23 (2008) 2619-2633.

[15] V.L. Rainha, I.T.E. Fonseca, Kinetic studies on the SRB influenced corrosion of steel: a first approach, Corros. Sci. 39 (1997) 807-813.

[16] D. Féron, I. Dupont, G. Novel, Influence of microorganisms on the free corrosion potential of stainless steels in natural seawaters, in: D. Thierry (Ed.), Aspects of Microbiologically Induced Corrosion, The Institute of Material, London, 1997, pp. 103-139.

[17] I.B. Beech, Sulfate-reducing bacteria in biofilms on metallic materials and corrosion, Microb. Today. 30 (2003) 115-117.

[18] H. Venzlaff , D. Enning , J. Srinivasan, K.J.J. Mayrhofer, A.W. Hassel, F. Widdel, M. Stratmann, Accelerated cathodic reaction in microbial corrosion of iron due to direct electron uptake by sulfate-reducing bacteria, Corros. Sci. 66 (2013) 88-96.

[19] M. Dubiel, C.H. Hsu, C.C. Chien, F. Mansfeld, D.K. Newman, Microbial Iron Respiration Can Protect Steel from Corrosion, Appl. Environ. Microb. 68 (2002) 1440-1445.

[20] K. Lee, D.K. Newman, Microbial iron respiration: impacts on corrosion processes, Appl. Microbiol. Biotechnol. 62 (2003) 134-139.

[21] L.K. Herrera, H.A. Videla, Role of iron-reducing bacteria in corrosion and protection of carbon steel, Inter. Biodeter. Biodegr. 63 (2009) 891-895.

[22] L. Esnault, M. Jullien, C. Mustin, O. Bildstein, M. Libert, Metallic corrosion processes reactivation sustained by iron-reducing bacteria: Implication on long-term stability of protective layers, Phys. Chem. Earth. 36 (2011) 1624-1629.

[23] M. Libert, L. Esnault, D. Féron, Biocorrosion en conditions de stockage géologique de déchets radioactifs, Matériaux \& Techniques, 99 (2011) 581-589.

[24] R. Moreira, M.K. Schütz, M. Libert, B. Tribollet, V. Vivier, Local Electrochemical Measurements Applied to Biocorrosion, Bioelectrochem. This issue.

[25] J.E. Kostka, K.H. Nealson, Isolation, cultivation, and characterization of iron- and manganese-reducing bacteria, in: Techniques in Microbial Ecology, Oxford University Press, New York, 1998, pp. 468.

[26] C. Gabrielli, S. Joiret, M. Keddam, H. Perrot, N. Portail, P. Rousseau, V. Vivier, A SECM assisted EQCM study of iron pitting, Electrochim. Acta. 52 (2007) 7706-7714.

[27] M. Keddam, N. Portail, D. Trinh, V. Vivier, Progress in Scanning Electrochemical Microscopy by Coupling with Electrochemical Impedance and Quartz Crystal Microbalance, Chem. Phys. Chem. 10 (2009) 3175-3182.

[28] P.G. Nicholson, S. Zhou, G. Hinds, A.J. Wain, A. Turnbull, Electrocatalytic activity mapping of model fuel cell catalyst films using scanning electrochemical microscopy, Electrochim. Acta. 54 (2009) 4525-4533. 
[29] D. Trinh, M. Keddam, X.R. Novoa, V. Vivier, Alternating Current Measurements in Scanning Electrochemical Microscopy, Part 2: Detection of Adsorbates, Chem. Phys. Chem. 12 (2011) 2177-2183.

[30] D.L.A. Faria, S.V. Silva, M.T. Oliveira, Raman Microspectroscopy of Some Iron Oxides and Oxyhydroxides, J. Raman Spectrosc. 28 (1997) 873-878.

[31] M. Hanesch, Raman spectroscopy of iron oxides and (oxy)hydroxides at low laser power and possible applications in environmental magnetic studies, Geophys. J. Int. 177 (2009) 941948.

[32] L. Bellot-Gurlet, D. Neff, S. Réguer, J. Monnier, M. Saheb, P. Dillmann, Raman studies of corrosion layers formed on archaeological irons in various media, JNanoR. 8 (2009) 147-156.

[33] R.L. Frost, W. Martens, P.A. Williams, J.T. Kloprogge, Raman and infrared spectroscopic study of the vivianite-group phosphates vivianite, baricite and bobierrite, Mineral. Mag. 66 (2002) 1063-1073.

[34] R.L. Frost, M.L. Weier, Raman spectroscopic study of vivianites of different origins. Neues Jb. Miner. Monat. 10 (2004) 445-463.

[35] F.H. Chapelle, K. O'Neill, P.M. Bradley, B.A. Methé, S.A. Ciufo, L.L. Knobel, D.R Lovley, A hydrogen-based subsurface microbial community dominated by methanogens, Nature. 415 (2002) 312-315.

[36] H.T. Dinh, J. Kuever, M. Mußmann, A.W. Hassel, M. Stratmann, F. Widdel, Iron corrosion by novel anaerobic microorganisms, Nature 427 (2004) 829-832.

[37] Y-S. Luu, J.A. Ramsay, Review: microbial mechanisms of accessing insoluble $\mathrm{Fe}(\mathrm{III})$ as an energy source. World J. Microb. Biot. 19 (2003) 215-225.

[38] J. Kwak, A.J. Bard, Scanning electrochemical microscopy. Theory of the feedback mode, Anal. Chem. 61 (1989) 1221-1227.

[39] C. Lemaitre, N Pébére, D. Festy, Biodétérioration des matériaux, EDP Sciences, 1998. 


\section{Scheme Captions}

Scheme 1: Sketch of the experimental setup for the local $\mathrm{H}_{2}$ generation by the platinum probe in a close vicinity of the carbon steel substrate. 


\section{Table Captions}

Table 1: M1 minimal medium composition.

Table 2: Determination of the exchanged charge (in millicoulomb) during the corrosion in different conditions (calculated from results presented in Figure 6) with the respective corrosion rates. 


\section{Figure Captions}

Figure 1: Production of $\mathrm{Fe}$ and $\mathrm{H}_{2}$ by carbon steel corrosion during the geochemical experiments $(n=3)$ : $\mathrm{Fe}(\bullet, \mathbf{\Lambda})$ and $\mathrm{H}_{2}(\cdot, \bullet)$ concentrations $(\mu \mathrm{M})$ as function of time (days). Biotic conditions $(\bullet, \bullet)$ and abiotic conditions $(\boldsymbol{\Lambda}, \bullet)$.

Figure 2: Raman spectra of corrosion products detected on steel coupons reacted during 5 months in the geochemical experiments. (a) Abiotic conditions: vivianite (i) and (iii); magnetite (ii). (b) Biotic conditions: vivianite (i) and (iii); magnetite (ii); and cellular compounds (iv). Each spectrum in the figures is representative of the signal collected on the sample surface.

Figure 3: SEM micrographs and EDS spectra of corrosion products formed by carbon steel corrosion after 5 months in the geochemical experiments. (a-d) Abiotic conditions: precipitate formed over the black layer (a, b) and black layer (c, d). (e-h) Biotic conditions: precipitate formed over the black layer $(e, f)$ and black layer $(g, h)$. The rectangle on SEM images corresponds to the areas analyzed by EDS.

Figure 4: Evolution of the OCP (V vs. SCE) as function of time (hours) of the carbon steel substrate before and after inoculation of Shewanella oneidensis during the electrochemical experiments.

Figure 5: SEM micrographs of carbon steel coupon reacted during 3 days in biotic conditions in the electrochemical experiments. (a) Global view of the coupon surface. (b) View of the center where the $\mathrm{H}_{2}$ generating probe was placed. (c) View of a single crystal formed. (d) EDS spectrum of the crystal shown in Figure $c$.

Figure 6: Chronoamperometric response $\left(\mu \mathrm{A} \mathrm{cm}^{-2}\right)$ as function of time (hours) of the carbon steel substrate in biotic conditions for electrochemical experiments. (a) No local $\mathrm{H}_{2}$ generation by the probe. (b) Without Shewanella oneidensis under a local $\mathrm{H}_{2}$ generation by the probe. (c) With both Shewanella oneidensis and local $\mathrm{H}_{2}$ generation by the probe.

Figure 7: SEM micrograph showing attachment of bacteria on the carbon steel surface after 10 days in the electrochemical experiments. The rectangle on SEM images indicates the cells of Shewanella oneidensis. No fixation treatment was performed for the analysis.

Figure 8: Corrosion rate $\left(\mu \mathrm{m}\right.$ year-1 ${ }^{-1}$ as function of time (days) measured at the outset of the geochemical experiments $(n=3)$ : biotic $(\bullet)$; and abiotic $(\boldsymbol{\Lambda})$ conditions. 


\section{SCHEME 1}

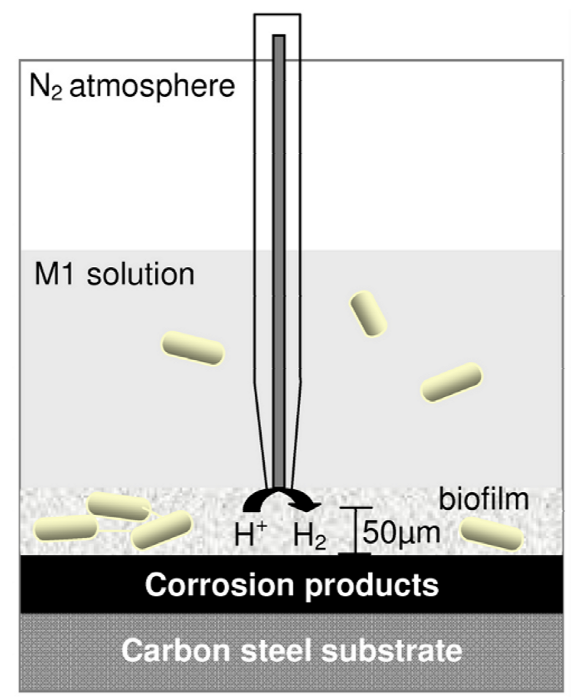


TABLE 1

\begin{tabular}{|c|c|}
\hline Compound & Concentration \\
\hline 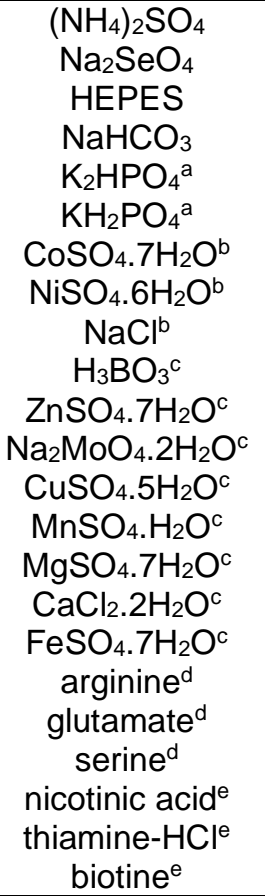 & $\begin{array}{c}9 \mathrm{mM} \\
11 \mu \mathrm{M} \\
17 \mathrm{mM} \\
2 \mathrm{mM} \\
0.5 \mathrm{mM} \\
0.3 \mathrm{mM} \\
5 \mu \mathrm{M} \\
5 \mu \mathrm{M} \\
10 \mu \mathrm{M} \\
45 \mu \mathrm{M} \\
0.8 \mu \mathrm{M} \\
3 \mu \mathrm{M} \\
0.2 \mu \mathrm{M} \\
1 \mu \mathrm{M} \\
0.8 \mathrm{mM} \\
0.4 \mathrm{mM} \\
4 \mu \mathrm{M} \\
0.11 \mathrm{mM} \\
0.13 \mathrm{mM} \\
0.19 \mathrm{mM} \\
0.08 \mathrm{mM} \\
0.01 \mathrm{mM} \\
0.40 \mu \mathrm{M}\end{array}$ \\
\hline
\end{tabular}

a Phosphate buffer solution

${ }^{b}$ Metals supplement solution

c Basal salts solution

${ }^{d}$ Amino acid solution

e Vitamins solution

TABLE 2

\begin{tabular}{c|c|c|c}
\hline Experiment & $\mathbf{q}(\mathbf{s t}$ corr) / (mC) & $\mathbf{q}\left(\mathbf{H}_{\mathbf{2}}\right.$ generation) / (mC) & $\boldsymbol{v}(\mathbf{c o r r}) /(\boldsymbol{\mu m} / \mathbf{y})^{\mathbf{c}}$ \\
\hline With bacteria without probe (Fig. 6a) & $216 \pm 11$ & --- & $7.3 \pm 0.4$ \\
\hline With probe without bacteria (Fig. 6b) & $430 \pm 22$ & $100 \pm 5$ & $14.5 \pm 0.7$ \\
\hline With probe and bacteria (Fig. 6c) & $1400 \pm 70$ & $100 \pm 5$ & $48.0 \pm 2.4$ \\
\hline
\end{tabular}

a Charge (steel corrosion)

${ }^{b}$ Charge ( $\mathrm{H}_{2}$ generation)

c Corrosion rate 


\section{FIGURE 1}

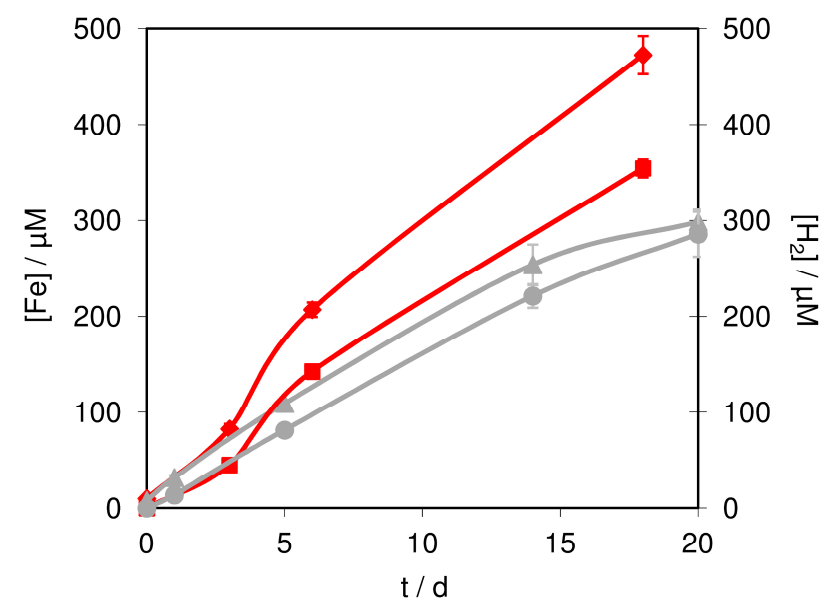

\section{FIGURE 2}
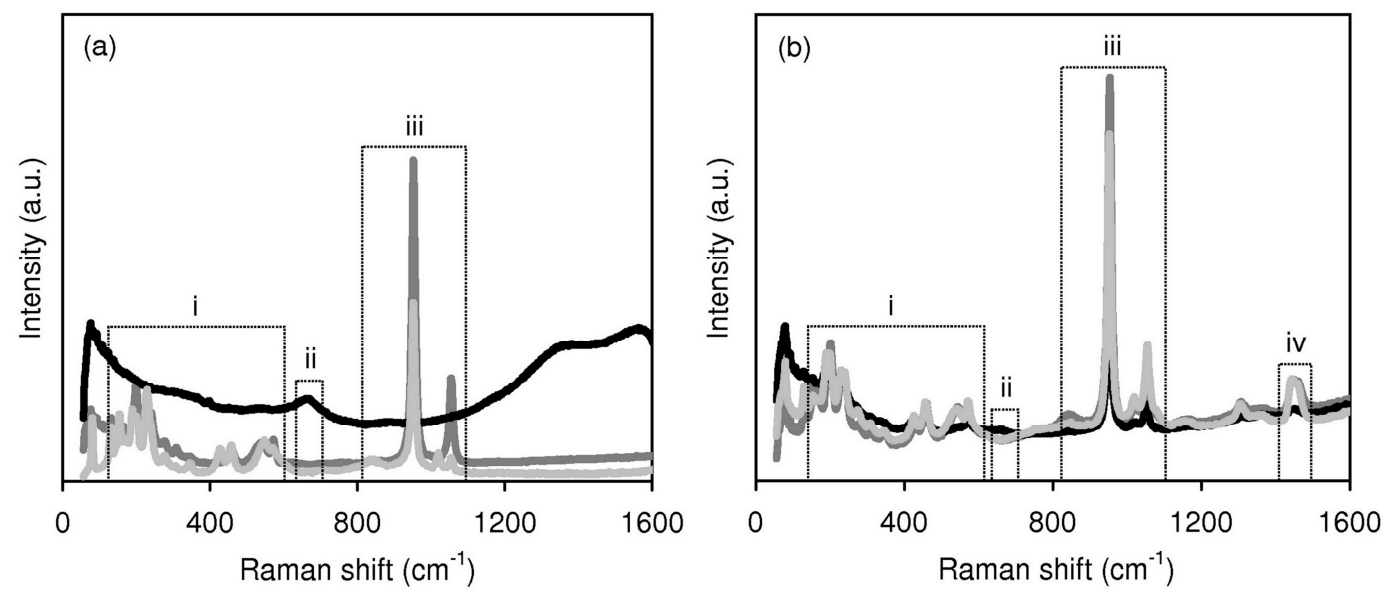
FIGURE 3
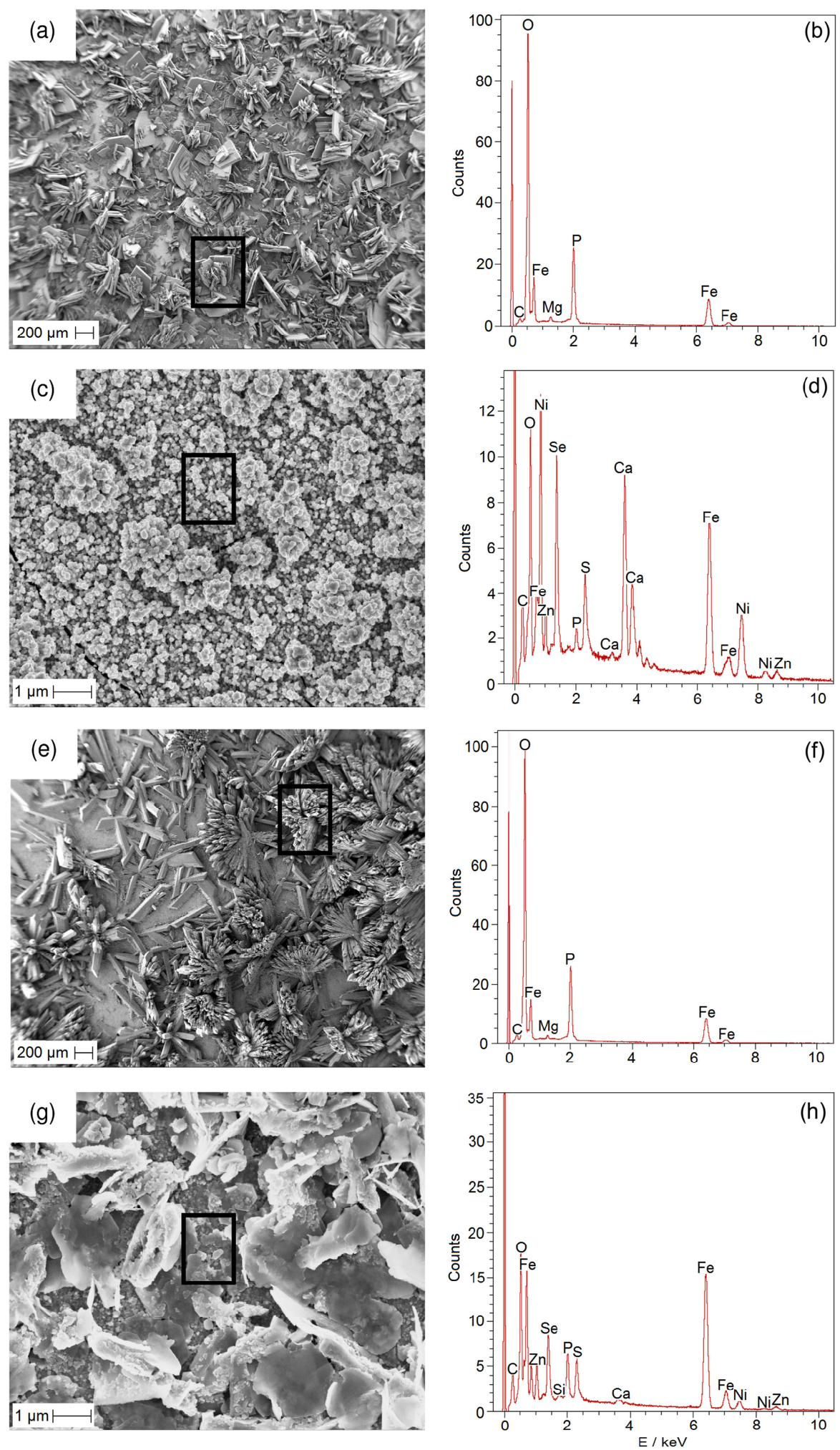


\section{FIGURE 4}

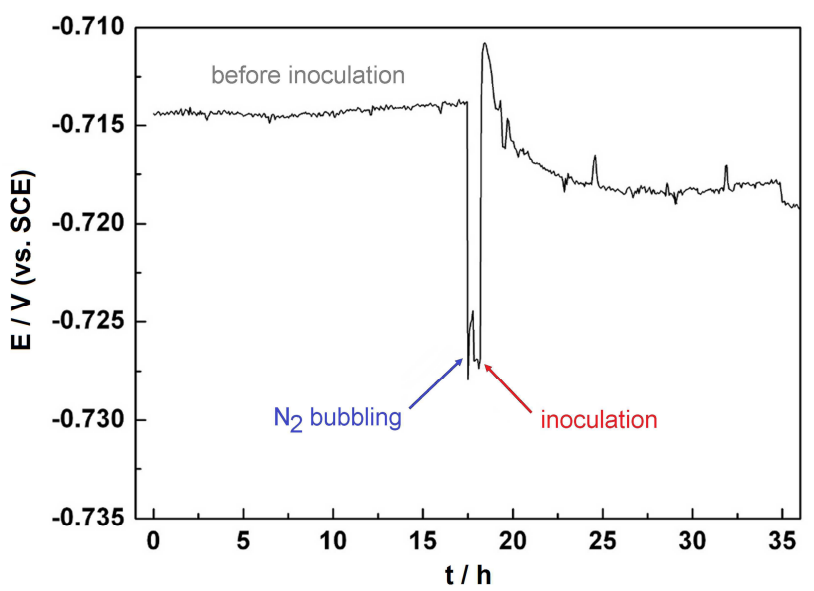

FIGURE 5
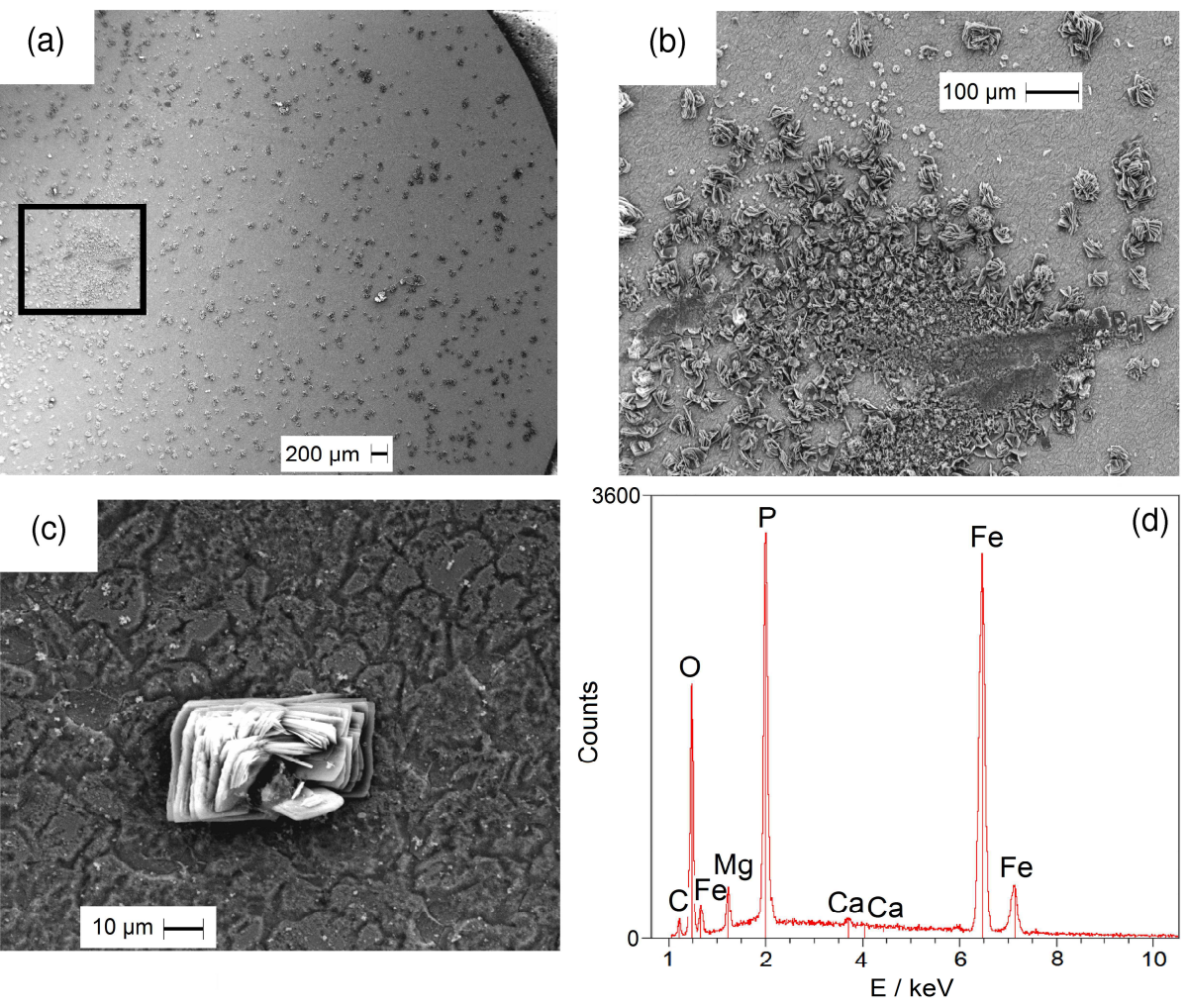


\section{FIGURE 6}

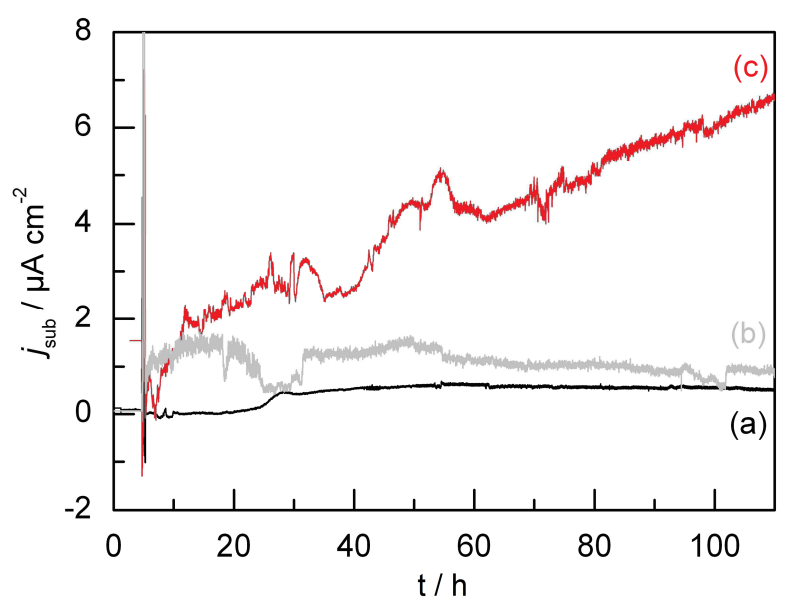

FIGURE 7

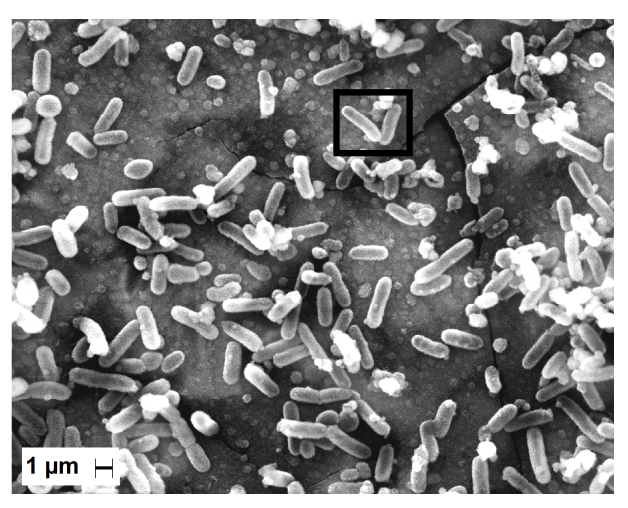

FIGURE 8

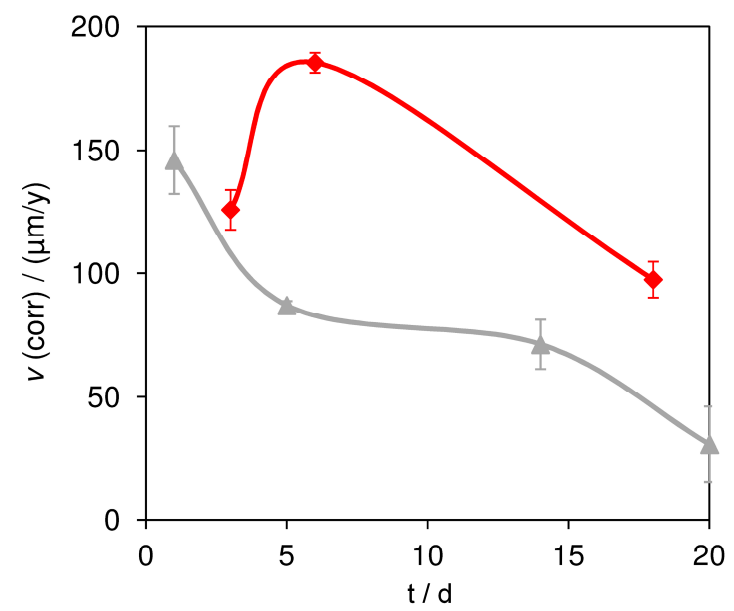

